\title{
ENTREPRENEURIAL CHARACTERISTICS ON ENTREPRENEURIAL TENDENCIES AS AGE MODERATED: A STUDY ON UNIVERSITY INDONESIA
}

\author{
Anggraini Voni ${ }^{\star}$, Rojuaniah, Syah Tantri Yanuar Rahmat \\ University of Esa Unggul, Indonesia \\ *E-mail: suryani.abbiya@gmail.com
}

\begin{abstract}
Having the spirit of entrepreneurial is very important for the young generation, seeing the number of unemployed and the lack of land for new workers. But not all young people have the spirit as an entrepreneur or a tendency to entrepreneurial. Especially for young students, they should have more enthusiasm to build their own business. Entrepreneurial has been carried out especially in universities, with the intention that young people are formed who are entrepreneurial oriented and live independently and of course the young generation who have their own business lines will increase the country's social economic growth. Therefore, the purpose of this study is to know the influence of entrepreneurial characteristics (innovativeness, achievement, locus of control, risk taking, tolerance for ambiguity and self confidence) towards entrepreneurial tendencies moderated by age-based demographics. Respondents involved in this study were 120 students. Data analysis was done using General Linear Model (GLM) method. The results showed innovativeness increased entrepreneurial tendencies, innovativeness increased entrepreneurial tendencies but was not moderated by age, achievement did not increase entrepreneurial tendencies, achievement did not increase the tendency of entrepreneurial be moderated by age, locus of control increasing entrepreneurial tendencies, locus of control increasing the tendency of entrepreneurship but not moderated by age, risk taking increased the tendency of entrepreneurial, risk taking increased the tendency of entrepreneurial but not moderated by age, tolerance for ambiguity increased the tendency of entrepreneurial, tolerance for ambiguity increased the tendency of entrepreneurial but not moderated by age, self confidence increased the tendency of entrepreneurial and self confidence increased the tendency of entrepreneurial but not moderated by age to students.
\end{abstract}

\section{KEY WORDS}

Innovativeness, achievement, locus of control, risk taking, tolerance for ambiguity.

Entrepreneurial has become an important issue among academics regarding its positive contribution to social and economic life. The nature of entrepreneurial personality is learned in order to know the characteristics of individuals who distinguish an entrepreneur and not an entrepreneur. To be able to achieve its goals, it requires attitude and supportive behavior in an entrepreneur. Some characteristics that have been of particular concern in the entrepreneurial literature are among others the need for achievement, locus of control, tolerance for ambiguity, self-confidence, creativity or innovation, the tendency to take risks and independence or freedom (Bezzina, 2010). But not all students have the spirit to be an entrepreneur or a tendency to entrepreneurship. This is due to the lack of experience, lack of business capital and faced with uncertainty causing anxiety to start a business independently.

Entrepreneurial education should be given to economic units through education modules as well as individuals who have a college level education degree. Entrepreneurial has been done a lot, especially in universities, with the intention of forming young people who are oriented towards entrepreneurship and independent living. But it is not uncommon to find some students who have received entrepreneurial education with a tendency to build their own business. Based on the research conducted by Gurol and Atsan (2006) a number of students in Turkey found no significant relationship between entrepreneurship learning in the classroom with the growing tendency of entrepreneurship that will continue to act in a 
real business. But the results of the study showed that, except for tolerance to ambiguity and self-confidence, all entrepreneurial traits were found to be higher in students who tended to be entrepreneurial, compared to students who tended to lack independence. This means, these students were found to have a tendency to take a higher risk, locus of control, higher needs for higher achievement and innovation.

Yusof, Sandhu and Jain (2008), its research aimed to know the extent to which young people tend to be entrepreneurial to Abdul Razak University students, Malaysia and the results showed young students were more likely to be entrepreneurs; they had a strong desire to own a business (85\%) and were interested to start their own business $(71 \%)$. Kume, Kume and Shahini (2013) analyzed entrepreneurship trends among students in Albania. The results of the study concluded that there is a relatively healthy level of interest in entrepreneurship among students in Albania. In this paper, students' tendency to entrepreneurship was examined together with several related variables (locus of control, entrepreneurial self-efficacy, independence motive and innovation).

Asamani and Mensah (2013), its research examined the level of entrepreneurial tendencies among Ghanaian university students, and the results of the study concluded that students in Ghana universities had a high level of entrepreneurial tendency. However, age, gender and academic programs of students were found to have no influence on their entrepreneurial tendencies. Meanwhile, students' personal characteristics such as leadership attributes, task performance attitudes, achievement attitudes and risk-taking attributes were found to have an influence on entrepreneurial tendencies.

Zaman (2013), analyzed the characteristics of entrepreneurship on entrepreneurial tendencies in students in Pakistan and the research showed that the need for achievement, locus of control, risk taking propensity, self-confidence, tolerance of ambiguity, and innovativeness influenced entrepreneurial tendencies in students in Pakistan. Furthermore, Edirisinghe and Nimeshi (2016), its study aimed to know the influence of entrepreneurial characteristics on entrepreneurial tendencies in Sri Lankan students. The results of the study conclude: need for achievement, locus of control, risk taking propensity, self confidence, and innovativeness influence entrepreneurial tendencies in the students of Kelaniya University, Sri Lanka. But the tolerance of ambiguity has no influence on entrepreneurial tendencies. Ibrahim and Saili (2017), its research was to assess the attitude of seaweed operators towards entrepreneurial tendencies. The results show that achievement, innovation and personal control are statistically significant towards temporary entrepreneurial tendencies, self-esteem does not show a significant relationship to entrepreneurial tendencies.

Referring to the research of Gurol and Atsan (2006); Asamanai and Mensah (2013), researchers tried to examine entrepreneurial trends and characteristics of entrepreneurship (the need for achievement, locus of control, tendency to take risks, tolerance for ambiguity, innovation and confidence) of regular students and executives at Esa Unggul University in Jakarta. But researchers tried to add demographic variables based on age, which students are the younger generation must be able to master the times and develop the potential and character in capturing various business opportunities to become a successful and qualified person at a young age.With regard to Esa Unggul University graduates, it is expected to have strong entrepreneurial awareness and desire. The many unique characteristics, the education business at Esa Unggul University faces severe challenges. Along with the rapid technological advances in the education business in this era of globalization

Based on the background stated, our aim in this study is to know the influence of entrepreneurial (innovativeness, achievement, locus of control, risk taking, tolerance for Ambiguty and self confidence) on entrepreneurial tendencies moderated by age-based demographics at Esa Unggul University Students, Indonesia.

\section{DEVELOPMENT OF HYPOTHESIS}

Innovation can be said to be the search for new ideas. Innovation is taken as one of the main characteristics in entrepreneurship (Gurol and Astan, 2006). Gurol and Atsan's (2006) research showed that there is an influence of innovation on entrepreneurial tendency, which 
means that there are significant differences between students who tend to be entrepreneurial and those who are not inclined to entrepreneurship related to innovation. Similarly, the research by Edirisinghe and Nimeshi (2016) showed that there is a positive influence between innovations on entrepreneurial tendency. Thus, increased innovation is expected to lead to greater entrepreneurial tendencies. Likewise with the research conducted by Yusof, et al. (2007); Kume, et. Al. (2013); Zaman (2013), which showed that there is an influence between achievement needs on entrepreneurial tendencies. From the literature above, the hypothesis that can be proposed is:

H1: Innovativeness increases the tendency of entrepreneurial in students.

Achievement motivation can be instilled through training in independence, respecting hard work and perseverance in achieving goals, and creating interest in excellence. McClelland's (2012) theory of the need for achievement is the most important of various psychological theories about entrepreneurship. In McClelland's theory (2012) emphasizes the relationship of achievement motivation or the need to excel in the development economy through entrepreneurial activities. Gurol and Atsan's research (2006) showed that there is an influence of achievement needs on entrepreneurial tendencies which means that there are significant differences between students who tend to be entrepreneurial and those who do not have entrepreneurship regarding the need for achievement. Similar to Yusof's research, et al. (2007); Zaman (2013), Edirisinghe and Nimeshi (2016) showed that there is a positive influence between achievement needs on entrepreneurial tendencies. Based on this explanation, the hypothesis that can be proposed is:

H2: Achievement increases the tendency of entrepreneurial in students.

The concept of personal control, although relatively new, has received much attention in the study of psychological differences (Phares, 1976). Personal control refers to one's beliefs about control over life events (Findley and Cooper, 1983). Gurol and Atsan's (2006) research showed that there is a locus of control influence on entrepreneurial tendencies which means that there are significant differences between entrepreneurial tendencies of students and those who do not tend to be entrepreneurial regarding personal control. Similar to Yusof's research, et al. (2007); Kume, et. Al. (2013); Zaman (2013); Edirisinghe and Nimeshi (2016), which concluded that there is an influence of locus of control with entrepreneurial tendencies. From the literature above, the hypothesis that can be proposed is:

H3: Locus of control increases the tendency of entrepreneurial in students.

The tendency of risk taking can be said to be an individual's current tendency to take or avoid risk (Petrakis, 2005). Employers are usually considered to be at risk when pursuing opportunities, and are often associated with creative and innovative actions (Koh, 1996). Therefore entrepreneurs are always confronted, either voluntarily or by force, challenges of uncertainty and financial potential and social losses when running their business. Gurol and Atsan's (2006) research showed that there is an influence between risk taking on entrepreneurial tendencies which means that there are significant differences between entrepreneurial tendencies of students and those who do not tend to be entrepreneurial with respect to taking risks. Similar to Yusof's research, et al. (2007); Asamani and Mensah (2013); Zaman (2013), Edirisinghe and Nimeshi (2016), which concluded that there is a risktaking influence with entrepreneurial tendencies. From the literature above, the hypothesis that can be proposed is:

H4: Risk taking increases the tendency of entrepreneurship in students.

Entrepreneurs not only operate in an uncertain environment, entrepreneurs eagerly do things that are unknown and voluntarily seek and manage uncertainty (Mitton, 1989). Dinis, et al. (2013) the results of his research, tolerance for ambiguity can be considered as an entrepreneurial characteristic and those who are more entrepreneurial are expected to display more tolerance for ambiguity than others. Yusof's research, et al. (2007); Zaman (2013); Edirisinghe and Nimeshi (2016) concluded that there is an influence between tolerance for ambiguity and entrepreneurial tendencies. From the literature above, the hypothesis that can be proposed is:

H5: Tolerance for ambiguity increases the tendency of entrepreneurial. 
Employers usually have confidence that is abundant in their ability to succeed. They tend to be optimistic about their chances of success. Gurol and Atsan's (2006) research showed that there is an influence between confidence in entrepreneurial tendencies which means that there are significant differences between entrepreneurial tendencies of students and those who do not tend to be entrepreneurial regarding self-confidence. Similar to Yusof's research, et al. (2007); Zaman (2013); Edirisinghe and Nimeshi (2016), which concluded that there is an influence between self-confidence and entrepreneurial tendencies. From the literature above, the hypothesis that can be proposed is:

H6: Self confidence increases the tendency of entrepreneurial.

Research by Ibrahim and Saili (2017) concluded that it is not surprising that data shows that most of the age of seaweed operators is actually between 30-39 years (34.6\%). The results are consistent with research conducted by Nor, Gary, Caldwell, and Stead (2016) where they found this age category to be the most common in seaweed cultivation in Semporna. Ali, et al. (2015) has explained that younger people do not like to look for agricultural jobs because they offer higher income and have better jobs compared to seaweed cultivation. Although the definition of innovation may vary, but for this research, it refers to the ability to innovate. This is reinforced by Lunkapis and Danny (2016) finding that local seaweed operators in Tun Sakaran Marine Park are willing to try new technologies but display adaptations that are slower than new changes. From the literature above, the hypothesis that can be proposed is:

H7: Innovativeness increases the tendency of entrepreneurial to be moderated by age demographics in students.

Research by Ibrahim and Saili (2017), concluded that the need for achievement shows an influence on entrepreneurial tendencies, there is a high level of achievement among seaweed operators. Similarly Collins, Hanges, and Locke (2004) found that achievement as an attitude is very important because it is able to accurately predict individual entrepreneurial activities. Interpretation can be justified through their perceived view of seaweed farming as energy. With regard to this, they must have high motivation and achievement commitments if they continue to work on agriculture. So it is not surprising that the data shows that most of the age of actual seaweed operators is between $30-39$ years (34.6\%). Where they found this age category as the most common in seaweed cultivation in Semporna. Younger people do not like to look for agricultural jobs because they offer higher income and have better jobs compared to seaweed cultivation. From the literature above, the hypothesis that can be proposed is:

H8: Achievement increases the tendency of entrepreneurial to be moderated by age demographics in students.

Research by Ibrahim and Saili (2017), concluded that locus of control reflects a person's beliefs about how far they are able to influence their results or success. The results showed significant personal control among seaweed operators. Therefore, as suggested, when their personal control increases, the tendency towards entrepreneurship will also increase proportionally. This is similar to research conducted by Bulut and Sayin (2010) where they found that people with high personal control tend to be entrepreneurs. So it is not surprising that the data shows that most of the age of actual seaweed operators is between 30-39 years (34.6\%). The results are consistent with research conducted by Nor, et al. (2016) where they found this age category to be the most common in seaweed cultivation in Semporna. Younger people do not like to look for agricultural jobs because they offer higher income and have better jobs compared to seaweed cultivation. From the literature above, the hypothesis that can be proposed is:

H9: Locus of control increases the tendency of entrepreneurial to be moderated by age demographics in students.

Fathoni's research (2015) concluded that a person's chronological age related to entrepreneurial age (the length of time a person becomes an entrepreneur). This means, with the increasing age of an entrepreneur, then the person would possess more experience in the field of business. With increasing experience when a person's age increases, age is indeed related to success. Dare to take risks, consisting of: being able to take risks and like 
challenges. In addition, psychological capital is also needed, namely psychological basic capital and personality that supports the characteristics of the entrepreneur to have an influence on business development. This is in accordance with research conducted by Staw in Riyanti (2003), age can be related to success when associated with the length of time a person becomes an entrepreneur. From the literature above, the hypothesis that can be proposed is:

H10: Risk taking increases the tendency of entrepreneurial to be moderated by age demographics in students.

Fathoni's research (2015) concluded that tolerance for ambiguity influences entrepreneurial tendencies, namely the characteristics of human-oriented entrepreneurship, consisting of: socializing with others, being flexible, responsive to suggestions/criticisms. Other conclusions confirm that a person's chronological age is related to entrepreneurial age (the length of time a person becomes an entrepreneur). This means, with the increasing age of an entrepreneur, then the person would possess more experience in the field of business. With the increasing experience when a person's age increases, age is indeed related to success. This is in accordance with research conducted by Staw in Riyanti (2003), age can be related to success when associated with the length of time a person becomes an entrepreneur. From the literature above, the hypothesis that can be proposed is:

H11: Tolerance ambiguity increases the tendency of entrepreneurial to be moderated by age demographics in students.

Ibrahim and Saili's research (2017) concluded that self-confidence influences entrepreneurial tendencies, in other words those who want to be decision makers must have higher self-confidence, a stronger mental focus and be very aware of what and where decisions will change. Research by Bulut and Sayin (2010) where they found that people with high self-confidence tend to be entrepreneurs. So it is not surprising that the data shows that most of the actual age of seaweed operators is between $30-39$ years (34.6\%). The results are similar to those of Nor, et al. (2016) where they found that this age category to be the most common in seaweed cultivation in Semporna. Younger people do not like to look for agricultural jobs because they offer higher income and have better jobs compared to seaweed cultivation. From the literature above, the hypothesis that can be proposed is:

H12: Self confident increases the tendency of entrepreneurial to be moderated by age demographics in students.

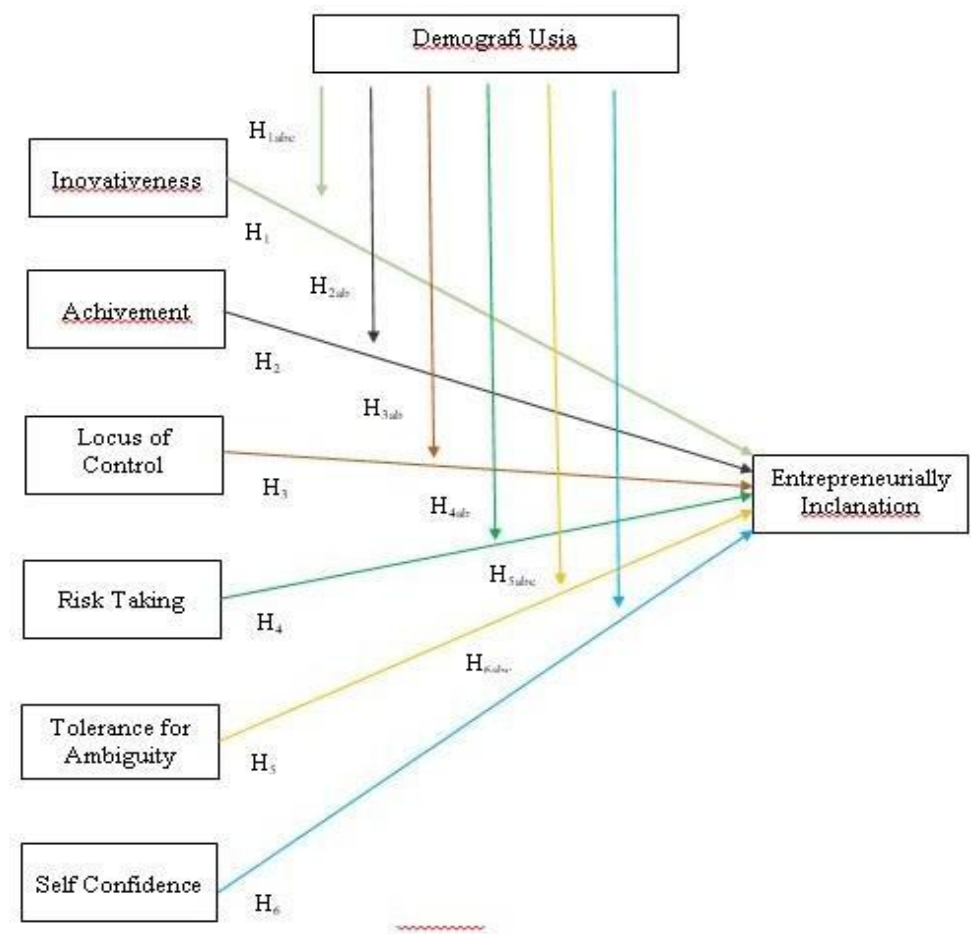

Figure 1 - Research Model 


\section{METHODS OF RESEARCH}

This research was conducted at Esa Unggul University executive and regular class students and female students. The aspects studied were the characteristics of entrepreneurial (innovativeness, achievement, locus of control, risk taking, tolerance for ambiguity and entrepreneurial inclination self confidence) and age-based demographics. The study was conducted in August 2018 with survey method. This research is descriptive. Data collection was carried out by distributing questionnaires to students and students of the executive and regular classes at Esa Unggul University, Indonesia. Data analysis method in this study used non-hierarchical statistics; the data was processed with the GLM (General Linear Model) statistical software. According to Agung (2006) the sample size used is the total number of cells averaged multiplied by 30 (minimum), where the number of cells was four (Table 1) thus $4 \times 30=120$ respondents.

Furthermore, the determination of the middle value or the median split from the variables innovativeness, achievement, locus of control, risk taking, tolerance for ambiguity, self confidence and age, which aims to divide the groups in cells from the respondents studied. To determine the median split, obtained from 120 respondents examined with valid results and the value of each respondent. Innovativeness, achievement, locus of control, risk taking, tolerance for ambiguity, self confidence and age, which aimed to divide the groups in cells from the respondents studied. To determine the median split, obtained from 120 respondents studied with valid results and the value of each respondent, as shown in the following table, is needed:

Table 1 - Result of Total Median Split

\begin{tabular}{|c|c|c|c|}
\hline \multicolumn{2}{|c|}{$\mathrm{n} / \mathrm{n}$} & Value Label & $\mathrm{N}$ \\
\hline \multirow{2}{*}{ Innovativeness } & 1.00 & High & 53 \\
\cline { 2 - 4 } & 2.00 & Low & 67 \\
\hline \multirow{2}{*}{ Achievement } & 1.00 & High & 67 \\
\cline { 2 - 4 } & 2.00 & Low & 53 \\
\hline \multirow{2}{*}{ Locus of control } & 1.00 & High & 64 \\
\cline { 2 - 4 } & 2.00 & Low & 56 \\
\hline \multirow{2}{*}{ Risk taking } & 1.00 & High & 59 \\
\cline { 2 - 4 } & 2.00 & Low & 61 \\
\hline \multirow{2}{*}{ Tolerance for ambiguity } & 1.00 & High & 65 \\
\cline { 2 - 4 } & 2.00 & Low & 55 \\
\hline \multirow{2}{*}{ Self confidence } & 1.00 & High & 60 \\
\cline { 2 - 4 } & 2.00 & Low & 60 \\
\hline \multirow{2}{*}{ Age } & 1.00 & Young & 60 \\
\cline { 2 - 4 } & 2.00 & Old & 60 \\
\hline
\end{tabular}

In our study, the independent variable are innovativeness, achievement, locus of control, risk taking, tolerance for ambiguity, self confidence, dependent variable is entrepreneurial tendencies while the role of motivation variable as a moderating variable that influences the independent variable and dependent variable. Measurement of innovativeness was adapted from Jackson (1994) in Mueler and Thomas (2000), variable of achievement the measurement was adapted form Rasheed (2003); Azis, Ishak, Ghani and Othman (2009); Bonnett and Furnham (1991); Taormina and Lao (2007). Measurement of locus of control was adapted from Rasheed (2003); Azis, et al. (2009); Bonnett and Furnham (1991); Luthje and Franke (2003); Birdthistle (2008). Measurement of risk taking was adapted from Sexton and Bowman (1985); Luthje and Franke (2003); Josien (2012). In measuring tolerance for ambiguity it was adapted from Yusof, et al., (2007) and measurement of self confidence was adapted from Bezzina (2010), then tested for validity and reliability.

This study used confirmatory factor analysis by validity testing to know the value of Kaiser-Meyer-Olkin sampling size (KMO) and sampling adequacy size (MSA). In this study, the value obtained must be greater than 0.500 with a component matrix one, which means that the analysis factor is correct or suitable for use, and can be further processed (Malhotra, 2007). The innovativeness scale consisted of 8 questionnaires, not all were valid IN8 (0.466), 
IN7 (0.573), IN1 (0.633), achievement scale consisted of 4 questionnaires and all were valid, locus of control scale consisted of 4 questionnaires and not all were valid, namely at LC4 (0.416), Risk taking scale consisted of 4 questionnaires and not all were valid, namely RT4 $(0,516)$, tolerance for ambiguity scale consisted of 4 questionnaires and all were valid, self confidence scale consisted of 2 questionnaires and all were valid. While on entrepreneurially scale inclannation consisted of 6 questionnaires and invalid in KW1 (0.570). Reliability test with Cronbach Alpha value> 0.5 which means reliable (Sugiyono, 2012), thus the questions of all variables can be said to be reliable as a data collection tool in research.

\section{RESULTS OF STUDY}

Innovativeness Increases Entrepreneurial Tendency Moderated by Age Demography. In this study, as can be seen in Table 2 where hypothesis $\mathrm{H} 1$ was tested by using the statistical $\mathrm{F}$ test on the lines of 'innovativeness and entrepreneurial tendencies' where F0 $=90.973$ (Sig. 0,000 ) with a degree of freedom of $1 / 116$.

This indicates a rejection against $\mathrm{HO}$, thus it can be concluded that the data supported the proposed hypothesis. This shows that innovativeness increases entrepreneurial tendencies in students at Esa Unggul University in Jakarta. The results of hypothesis 1 moderation found the results of the values to be tested to see the difference in entrepreneurially inclination $(\mathrm{Y})$ mean gap which was formed by high innovativeness (IN) (IN $=1$ ), low innovativeness $(I N=2)$ good for young respondents $(U=1)$ and the respondents of old age $(U=2)$ after calculating the same influence of linear innovativeness $(X)$ on entrepreneurially inclination $(Y)$ in all cells.

The results of the analysis supported hypothesis $\mathrm{H} 1 \mathrm{a}$, specifically for the respondent group with the level of old age, the group of respondents with high innovativeness had a greater entrepreneurial tendency compared to the group of respondents who had low innovativeness $(\beta 1)$ with sig. values. $0.000(<0.05)$. In the results of the hypothesis test $1 \mathrm{~b}$, found the results of the analysis did not support the hypothesis that specifically for groups of respondents with high innovativeness, the group of respondents with a young age level had a tendency to entrepreneurship greater than old age ( $\beta 2)$ with a sig. value. $0.785(>0.05)$. In the results of the hypothesis $1 \mathrm{c}$ test, it was found that the results did not support hypothesis $\mathrm{H} 1 \mathrm{c}$, specifically for the group of respondents with low innovativeness, the group of respondents with a young age level had a greater tendency to entrepreneurship compared to old age $(\beta 3)$ with a sig. value $0.146(>0.05)$.

Table 2 - Test of Between-Subject Effects Innovativeness

Dependent Variable: El.

\begin{tabular}{|c|c|c|c|}
\hline Source & df & F & Sig \\
\hline Corrected Model & 3 & 30.956 & 0.000 \\
\hline Intercept & 1 & 15349.656 & 0.000 \\
\hline INMEDIAN & 1 & 90.973 & 0.000 \\
\hline INMEDIAN*USIA & 2 & 1.110 & 0.333 \\
\hline Error & 116 & & \\
\hline Total & 120 & & \\
\hline Corrected Total & 119 & & \\
\hline
\end{tabular}

Source: Test results on data analysis tools.

Achievement does not Increase Entrepreneurial Tendency Moderated by Age Demography. In this study, as can be seen in Table 3 where the hypothesis $\mathrm{H} 2$ test used statistical $F$ test on the line 'achievement and entrepreneurial tendencies 'where $F 0=1,299$ (Sig. 0,257 ) with a degree of freedom of $1 / 116$. This indicates the presence of $\mathrm{HO}$ was accepted, so it can be concluded that the data did not support the hypothesis proposed. This shows that achievement does not increase entrepreneurial tendencies in students at Esa Unggul University in Jakarta. The results of hypothesis 2 moderation found the results of the values to be tested to see differences in the average entrepreneurial inclusion gap $(Y)$ 
formed by high achievement $(\mathrm{ACH})(\mathrm{ACH}=1)$, low achievement $(\mathrm{IN}=2)$ both in young respondents $(U=1)$ and the respondents of old age $(U=2)$ after calculating the same influence of linear innovativeness $(X)$ on entrepreneurially inclination $(Y)$ in all cells.

The results of the analysis supported hypothesis $\mathrm{H} 2 \mathrm{a}$ that specifically for the respondent group with the old age level, the high achievement group of respondents had a greater entrepreneurial tendency compared to the low achievement respondents group ( $\beta 1$ ) with sig. values $0.404(>0.05)$. On the results of hypothesis $2 b$ testing, found the results of the analysis did not support the hypothesis, that was specifically for groups with high achievement respondents, groups of respondents with a young age had a greater tendency to entrepreneurship than old age ( $\beta 2)$ with sig. values $0.489(>0.05)$. In the results of the hypothesis $2 \mathrm{c}$ test, found the results did not support the hypothesis that specifically for the low achievement group of respondents, the group of respondents with a young age level, had a greater tendency to entrepreneurship compared to the elderly $(\beta 3)$ with sig. values $0,572(>0,05)$.

Table 3 - Test of Between-Subject Effects Achievement

Dependent Variable: El.

\begin{tabular}{|c|c|c|c|}
\hline Source & df & F & Sig \\
\hline Corrected Model & 3 & 0,668 & 0,573 \\
\hline Intercept & 1 & 8474,101 & 0,000 \\
\hline ACHMEDIAN & 1 & 1,299 & 0,257 \\
\hline ACHMEDIAN*USIA & 2 & 0,401 & 0,670 \\
\hline Error & 116 & & \\
\hline Total & 120 & & \\
\hline
\end{tabular}

Source: Test results on data analysis tools.

Locus of Control Increases Entrepreneurial Tendency Moderated by Age Demography. In this study, as can be seen in Table 4 where hypothesis $\mathrm{H} 3$ was tested using the statistical $F$ test on the line "locus of control and entrepreneurial tendencies" wherein F0 = 37,291 (Sig. 0,000 ) with a free degree of $1 / 116$. This indicates the existence of $\mathrm{H} 0$ was rejected, so it can be concluded that the data supported the proposed hypothesis. This shows that locus of control increases the tendency of entrepreneurship in students at Esa Unggul University Jakarta. The results of hypothesis 3 moderation found the results of the values to be tested to see differences in the average entrepreneurially inclination gap $(Y)$ formed by high locus of control $(L C)(L C=1)$, low locus of control $(L C 2=2)$ both at young respondents $(U=1)$ and old age respondents $(U=2)$ after calculating the same linear locus of control $(X)$ influence on entrepreneurially inclination $(Y)$ in all cells.

Table 4 - Test of Between-Subject Effects Locus of Control

Dependent Variable: El.

\begin{tabular}{|c|c|c|c|}
\hline Source & df & F & Sig \\
\hline Corrected Model & 3 & 12.746 & 0.000 \\
\hline Intercept & 1 & 11140.976 & 0.000 \\
\hline LCMEDIAN & 1 & 37.291 & 0.000 \\
\hline LCMEDIAN $^{*}$ USIA & 2 & 0.693 & 0.502 \\
\hline Error & 116 & & \\
\hline Total & 120 & & \\
\hline Corrected Total & 119 & & \\
\hline
\end{tabular}

Source: Test results on data analysis tools.

The results of the analysis supported hypothesis $\mathrm{H} 3 \mathrm{a}$ that was specifically for the group of respondents with the level of old age, the group of respondents with high locus of control had a greater tendency to entrepreneurship than the group of respondents who had a low locus of control $(\beta 1)$ with sig. values. $0,000(<0,05)$. In the results of hypothesis $2 b$ testing, 
the results of the analysis found that it did not support the hypothesis, specifically for the group of respondents with high locus of control. Respondents with a young age group had a greater entrepreneurial tendency than old age $(\beta 2)$ with sig. values $0.473(>0.05)$. In the results of hypothesis $2 \mathrm{c}$ test, found the results did not support the hypothesis that specifically for the group of respondents with low locus of control, the group of respondents with a young age level, had a tendency towards entrepreneurship greater than the elderly ( $\beta 3)$ with sig. $0.353(>0,05)$.

Risk Taking Increases Entrepreneurially Tendency Moderated by Age Demography. In this study, as can be seen in Table 5 where hypothesis $\mathrm{H} 4$ was tested using statistical $\mathrm{F}$ test on the line "risk taking and entrepreneurial tendency" where F0 $=46.798$ (Sig. 0,000) with a free degree of $1 / 116$. This indicates the existence of $\mathrm{HO}$ was rejected, so it can be concluded that the data supported the proposed hypothesis. This shows that risk taking increased the tendency of entrepreneurship for students at Esa Unggul University Jakarta. The results of hypothesis 4 moderation found the results of the values to be tested to see the difference in the average entrepreneurially inclination (Y) gap that was formed by high risk taking (RT) $(R T=1)$, low risk taking $(R T=2)$ both for the age respondents young $(U=1)$ and old age respondents $(U=2)$ after calculating the same linear risk taking $(X)$ influence on entrepreneurially inclination $(Y)$ in all cells.

The results of the analysis supported hypothesis $\mathrm{H} 4 \mathrm{a}$ namely specifically for the respondent group with the level of old age, the high risk taking group of respondents had a greater entrepreneurial tendency compared to the group of respondents who had low risk taking $(\beta 1)$ with sig. values $0,000(<0.05)$. In the results of hypothesis $4 \mathrm{~b}$ testing, the results of the analysis did not support the hypothesis namely specifically for the high risk taking group of respondents, the respondents with a young age group had a greater entrepreneurial tendency than old age $(\beta 2)$ with sig. values $0.780(>0.05)$. In the results of hypothesis $4 c$ test, the results found did not support the hypothesis namely specifically for the group of respondents with low risk taking, the group of respondents with a young age level had a tendency to entrepreneurship was greater than the elderly us ( $\beta 3$ ) with a sig. value 0,595 (> 0.05).

Table 5 - Test of Between-Subject Effects Risk Taking

Dependent Variable: El.

\begin{tabular}{|c|c|c|c|}
\hline Source & df & F & Sig \\
\hline Corrected Model & 3 & 16.025 & 0.000 \\
\hline Intercept & 1 & 11883.959 & 0.000 \\
\hline RTMEDIAN & 1 & 46.798 & 0.000 \\
\hline RTMEDIAN ${ }^{*}$ USIA & 2 & 0.181 & 0.834 \\
\hline Error & 116 & & \\
\hline Total & 120 & & \\
\hline Corrected Total & 119 & & \\
\hline
\end{tabular}

Source: Test results on data analysis tools.

Tolerance for Ambiguity Increases Entrepreneurially Tendency Moderated by Age Demography. In this study, as can be seen in Table 6 where the hypothesis H5 was tested by using statistical $\mathrm{F}$ test on the line "tolerance for ambiguity and entrepreneurial tendencies" where F0 = 74.767 (Sig. 0,000) with a free degree of 1/116. This indicates the existence of $\mathrm{HO}$ was rejected, so it can be concluded that the data supported the proposed hypothesis. This shows the tolerance for ambiguity increases the tendency of entrepreneurship in students at University of Esa Unggul Jakarta. The results of hypothesis 5 moderation found the results of the values tested to see the difference in entrepreneurially inclination $(Y)$ mean gap which was formed by high tolerance for ambiguity $(T A)(T A=1)$, tolerance for low ambiguity $(T A=2)$ both on young respondents $(U=1)$ and old age respondents $(U=2)$ after calculating the same influence of linear tolerance for ambiguity $(X)$ on entrepreneurially inclination $(\mathrm{Y})$ in all cells. 
Table 7 - Test of Between-Subject Effects Self Confidence

Dependent Variable: El.

\begin{tabular}{|c|c|c|c|}
\hline Source & $\mathrm{df}$ & $\mathrm{F}$ & Sig \\
\hline Corrected Model & 3 & 19.754 & 0.000 \\
\hline Intercept & 1 & 12826.094 & 0.000 \\
\hline SCMEDIAN & 1 & 56.551 & 0.000 \\
\hline SCMEDIAN*USIA & 2 & 1.130 & 0.326 \\
\hline Error & 116 & & \\
\hline Total & 120 & & \\
\hline Corrected Total & 119 & & \\
\hline
\end{tabular}

Source: Test results on data analysis tools.

Table 8 - Research Model Hypothesis Testing

\begin{tabular}{|c|c|c|c|}
\hline Hypothesis & Statement of Hypothesis & $\begin{array}{l}\text { Sig. } \\
\text { Value }\end{array}$ & Note \\
\hline \multicolumn{4}{|c|}{ Innovativeness } \\
\hline $\mathrm{H} 1$ & Innovativeness increases the tendency of entrepreneurial in students. & 0,000 & $\begin{array}{l}\text { Data supports } \\
\text { hypothesis }\end{array}$ \\
\hline \begin{tabular}{|c|}
$\mathrm{H} 1$ \\
Moderated
\end{tabular} & $\begin{array}{c}\text { Innovation increases the tendency of entrepreneurial moderated by } \\
\text { age demography in students. }\end{array}$ & 0,333 & $\begin{array}{l}\text { Data does not support } \\
\text { hypothesis }\end{array}$ \\
\hline \multicolumn{4}{|c|}{ Achievement } \\
\hline $\mathrm{H} 2$ & Achievement increases the tendency of entrepreneurial in students. & 0,257 & $\begin{array}{l}\text { Data does not support } \\
\text { hypothesis }\end{array}$ \\
\hline $\begin{array}{c}\mathrm{H} 2 \\
\text { Moderasi }\end{array}$ & $\begin{array}{c}\text { Achievement increases the tendency of entrepreneurship moderated } \\
\text { by age demography in students. }\end{array}$ & 0,670 & $\begin{array}{l}\text { Data does not support } \\
\text { the hypothesis }\end{array}$ \\
\hline \multicolumn{4}{|c|}{ Locus of control } \\
\hline H3 & $\begin{array}{l}\text { Locus of control increases the tendency of entrepreneurial in } \\
\text { students. }\end{array}$ & 0,000 & $\begin{array}{l}\text { Data supports } \\
\text { hypothesis }\end{array}$ \\
\hline $\begin{array}{c}\mathrm{H} 3 \\
\text { Moderasi }\end{array}$ & $\begin{array}{l}\text { Locus of control increases the tendency of entrepreneurial } \\
\text { moderated by age demographics in students. }\end{array}$ & 0,502 & $\begin{array}{l}\text { Data does not support } \\
\text { hypothesis }\end{array}$ \\
\hline \multicolumn{4}{|c|}{ Risk taking } \\
\hline $\mathrm{H} 4$ & Risk taking increases the tendency of entrepreneurial in students. & 0,000 & $\begin{array}{l}\text { Data supports } \\
\text { hypothesis }\end{array}$ \\
\hline \begin{tabular}{|c|}
$\mathrm{H} 4$ \\
Moderated \\
\end{tabular} & $\begin{array}{c}\text { Risk taking increases the tendency of entrepreneurial moderated by } \\
\text { age demographics in students. }\end{array}$ & 0,834 & $\begin{array}{c}\text { Data does not } \\
\text { support hypothesis }\end{array}$ \\
\hline \multicolumn{4}{|c|}{ Tolerance for ambiguity } \\
\hline H5 & $\begin{array}{c}\text { Tolerance for ambiguity increases the tendency of entrepreneurial in } \\
\text { students. }\end{array}$ & 0,000 & $\begin{array}{l}\text { Data supports } \\
\text { hypothesis }\end{array}$ \\
\hline \begin{tabular}{|c|}
$\mathrm{H} 5$ \\
Moderated \\
\end{tabular} & $\begin{array}{l}\text { Tolerance for ambiguity increases the tendency of entrepreneurial } \\
\text { moderated by age demography in students. }\end{array}$ & 0,134 & $\begin{array}{l}\text { Data does not support } \\
\text { hypothesis }\end{array}$ \\
\hline \multicolumn{4}{|c|}{ Risk taking } \\
\hline $\mathrm{H} 4$ & Risk taking increases the tendency of entrepreneurial in students. & 0,000 & $\begin{array}{l}\text { Data supports } \\
\text { hypothesis }\end{array}$ \\
\hline \begin{tabular}{|c|}
$\mathrm{H} 4$ \\
Moderated
\end{tabular} & $\begin{array}{c}\text { Risk taking increases the tendency of entrepreneurial moderated by } \\
\text { age demographics in students. }\end{array}$ & 0,834 & $\begin{array}{l}\text { Data does not } \\
\text { support hypothesis }\end{array}$ \\
\hline \multicolumn{4}{|c|}{ Tolerance for ambiguity } \\
\hline H5 & $\begin{array}{l}\text { Tolerance for ambiguity increases the tendency of entrepreneurial in } \\
\text { students. }\end{array}$ & 0,000 & $\begin{array}{l}\text { Data supports } \\
\text { hypothesis }\end{array}$ \\
\hline \begin{tabular}{|c|}
$\mathrm{H} 5$ \\
Moderated \\
\end{tabular} & $\begin{array}{l}\text { Tolerance for ambiguity increases the tendency of entrepreneurial } \\
\text { moderated by age demography in students. }\end{array}$ & 0,134 & $\begin{array}{c}\text { Data does not } \\
\text { support hypothesis }\end{array}$ \\
\hline \multicolumn{4}{|c|}{ Self Confidence } \\
\hline $\mathrm{H} 6$ & $\begin{array}{c}\text { Self confidence increases the tendency of entrepreneurial in } \\
\text { students. }\end{array}$ & 0,000 & $\begin{array}{l}\text { Data supports } \\
\text { hypothesis }\end{array}$ \\
\hline \begin{tabular}{|c|}
$\mathrm{H} 6$ \\
Moderated \\
\end{tabular} & $\begin{array}{c}\text { Self confidence increases the tendency of entrepreneurial moderated } \\
\text { by age demography in students. }\end{array}$ & 0,326 & $\begin{array}{c}\text { Data does not } \\
\text { support hypothesis }\end{array}$ \\
\hline
\end{tabular}

The results of the analysis supported hypothesis H5a which is specifically for the group of respondents with the level of old age, the group of respondents with tolerance for high ambiguity had a greater entrepreneurial tendency than the group of respondents who had tolerance for low ambiguity $(\beta 1)$ with sig. values $0,000(<0.05)$. In the results of hypothesis $5 b$ testing, found the results of the analysis did not support the hypothesis that was specifically 
for the group of respondents with tolerance for high ambiguity, the group of respondents with a young age had a tendency to entrepreneurship greater than old age $(\beta 2)$ with sig. values 0.052 (> 0.05). In the results of hypothesis $5 \mathrm{c}$ test, found the results did not support the hypothesis that specifically for the group of respondents with tolerance for low ambiguity, the group of respondents with a young age level, had a tendency to entrepreneurship greater than the old age $(\beta 3)$ with sig. value $0.644(>0.05)$.

Self confidence Increases Entrepreneurially Tendency Moderated by Age Demography. In this study, as can be seen in Table 7 where the hypothesis $\mathrm{H} 6$ was tested by using statistical $\mathrm{F}$ test on the line "self confidence and entrepreneurial tendencies" where $\mathrm{F} 0=56.551$ (Sig. 0,000) with a free degree of 1/116. This indicates the existence of H0 was rejected, so it can be concluded that the data supported the proposed hypothesis. This shows that self confidence increases the tendency of entrepreneurship in students at Esa Unggul University, Jakarta. The results of hypothesis 6 moderated found the results of the values to be tested to see differences in the average entrepreneurially inclination ( $Y$ ) gap that was formed by high self confidence $(S C)(S C=1)$, low self confidence $(S C=2)$ both in the age of young respondents $(U=1)$ and old age respondents $(U=2)$ after calculating the same influence of linear self confidence $(X)$ on entrepreneurially inclination $(Y)$ in all cells.

The results of the analysis supported hypothesis $\mathrm{H} 6 \mathrm{a}$ namely specifically for the group of respondents with the level of old age, the group of respondents with high self-confidence had a tendency to entrepreneurship greater than the group of respondents with low selfconfidence $(\beta 1)$ with sig. values $0,000(<0.05)$. In the results of hypothesis testing $5 b$, the results of the analysis did not support the hypothesis that specifically for the group of high self-confidence respondents, the group of respondents with a young age had a greater entrepreneurial tendency than old age $(\beta 2)$ with sig. values $0.714(>0.05)$. In the results of the hypothesis $5 \mathrm{c}$ test, found that the results did not support the hypothesis that specifically for the group of respondents with low self-confidence, the group of respondents with a young age level, had a tendency towards entrepreneurship greater than the elderly ( $\beta 3)$ with sig. values $0,148(>0,05)$.

\section{DISCUSSION OF RESULTS}

Analysis of Innovativeness Increases the Tendency of Entrepreneurial Moderated by Age Demography. In the test results, it showed innovativeness increased the tendency of entrepreneurship in students at Esa Unggul University Jakarta. Innovativeness increases entrepreneurial tendencies but not moderated by the age demography of students at Esa Unggul University Jakarta. Especially for the respondent group with the level of old age, the group with high innovation respondents had a greater tendency to entrepreneurship compared to the group of respondents who had low innovation. Namely specifically for the respondent group with high innovative, the group of respondents with a young age does not have a tendency to entrepreneurship that is greater than old age. The respondent group with low innovation, the group of respondent with a young age, did not have a tendency to entrepreneurship greater than the old age. Age demography is a life span measured by years, the level of maturity of a person in living life thus age is a benchmark in one's maturity in determining attitudes in entrepreneurship, although age cannot be used as someone to say successful or unsuccessful in entrepreneurship. Furthermore, the results of this study are in line with the research of Zaman (2013); Edirisinghe and Nimeshi, et al. (2016); Ibrahim and Saili (2017) concluded that there is a tendency of students to do entrepreneurship determined by innovativeness. And also researcher Yusof, et al. (2008); Kume, et al. (2013) concluded that young students are more likely to be entrepreneurs.

Analysis of Achievement Does Not Increase the Tendency of Entrepreneurial Moderated by Age Demography. The results of the study showed that achievement did not increase the tendency of entrepreneurship in students at Esa Unggul University Jakarta. Achievement did not increase the tendency of entrepreneurship moderated by age demography in students at Esa Unggul University Jakarta. Especially for the respondent group with the level of old age, the high achievement group of respondents did not have a 
greater entrepreneurial tendency compared to the low achievement group of respondents. For group with high achievement respondents, group of respondents with a young age did not have an entrepreneurial tendency greater than old age. Low achievement group of respondents, group of respondents with a young age, did not have a greater entrepreneurial tendency compared to old age. The age demographic level on the results of this hypothesis showed that old age or mature was not a guarantee that students would be capable of things and brave to make decisions on entrepreneurship, because what is needed to be brave in making these decisions is a high achievement level, although the demographic level is younger. This research is not in line with Zaman (2013) and Kume, et al. (2013) which concluded that need for achievement influenced entrepreneurial tendencies.

Analysis of Locus of Control Increases the Tendency of Entrepreneurial Moderated by Age. In the test results showed locus of control increased the tendency of entrepreneurship in students at Esa Unggul University Jakarta. Locus of control did not increase the tendency of entrepreneurship moderated by age demography in students at Esa Unggul University Jakarta. Especially for the respondent group with the level of old age, the group of respondent with high locus of control had a greater tendency to entrepreneurship compared to the group of respondents who had a low locus of control. Especially for group of respondent with high locus of control, the respondent group with a young age did not have an entrepreneurial tendency greater than old age. For group of respondent with low locus of control, the respondent group with a young age level did not have a greater entrepreneurial tendency compared to old age. Young age courage in taking a business decision is sometimes not owned by students with maturity or old age. Older age is more consideration in making a decision. This study is in line with Kume, et al. (2013); Edirisinghe and Nimeshi (2016) which concluded that locus of control influences students' tendency to entrepreneurship.

Analysis of Risk Taking Increases the Tendency of Entrepreneurship Moderated by Age Demography. The test results showed that risk taking increased the tendency of entrepreneurship in students at Esa Unggul University Jakarta. Risk taking increased the tendency of entrepreneurship but was not moderated by the age demographics of students at Esa Unggul University Jakarta. Especially for the respondent group with the level of old age, the high risk taking respondents group had a greater entrepreneurial tendency compared to the group of respondents who had low risk taking. That is specifically for high risk taking groups of respondents, the group of respondents with a young age did not have an entrepreneurial tendency greater than old age. Respondent group with low risk taking, group of respondents with a young age level, did not have a greater entrepreneurial tendency compared to old age. Demographics of old age are directly proportional to high risk taking because, in this phase of old age it is usually in the decision making whether the decision is risky or not, the person is ready for the consequences that will occur. Therefore, in doing business and entrepreneurship someone's maturity is needed both age and understanding of risk taking. This is in line with Zaman (2013) which showed that risk taking is one indicator of students' tendency to entrepreneurship, and Edirisinghe and Nimeshi (2016), with the results of this study concluding that risk taking propensity influences entrepreneurial tendencies in students.

Analysis of Tolerance for Ambiguity Increases Tolerance for Ambiguity Increases the Tendency of Entrepreneurial Moderated by Age Demography. On the test results showed that tolerance for ambiguity increases the tendency of entrepreneurship in students at Esa Unggul University Jakarta. Tolerance for ambiguity increases the tendency of entrepreneurship but is not moderated by age demographics in students at Esa Unggul University Jakarta.

Especially for group of respondents with old age levels, group of respondents with tolerance for high ambiguity had greater entrepreneurial tendencies compared to the group of respondents with tolerance for low ambiguity. That is specifically for the respondent group with tolerance for high ambiguity, the group of respondents with a young age level had a greater tendency to entrepreneurship than old age. For groups of respondents with tolerance for low ambiguity, groups of respondents with a young age level had a greater tendency to 
entrepreneurship compared to old age. Among UEU students, students with a tolerance for high ambiguity were proportionally straight with the old age demographics to try to do business and entrepreneurship due to the analysis of the possibilities of risk that is quite large, therefore it requires sufficient mindset and age maturity, so with this fact that old age and tolerance for high ambiguity among students is wide open to entrepreneurship compared to groups of students with tolerance for low ambiguity. This is not in line with the research by Zaman (2013) who stated tolerance for ambiguity influenced entrepreneurial tendencies in students.

Analysis of Self Confidence Increases the tendency of entrepreneurial moderated by age demography. On the test results showed self confidence increased the tendency of entrepreneurship in students at Esa Unggul University Jakarta. Self confidence increased the tendency of entrepreneurship but not moderated by age demographics in students at Esa Unggul University Jakarta. Especially for the respondent group with the level of old age, the group of respondents with high self-confidence had a tendency to entrepreneurship that was greater than the group of respondents who had low self-confidence. Namely specifically for the respondent group with high self confidence, the respondent group with a young age did not have an entrepreneurial tendency greater than old age. Hypothesis for the group of respondents with low self-confidence, the respondent group with a young age level did not have a greater entrepreneurial tendency compared to old age. Entrepreneurship can be done by anyone, especially someone who has high confidence in the business, but with a low level of confidence one can still conduct entrepreneurship if supported by a young age demographic level, because at a young age many opportunities can be achieved in the future ahead, therefore confidence in the cycle of time would grow one's confidence. This is in line with the researchers Edirisinghe and Nimeshi (2016), the results of the study concluded that self-confidence influences the entrepreneurial tendency of students.

\section{CONCLUSION}

The results that can be concluded from this study, first innovativeness can increase the tendency of entrepreneurial in students at UEU. The second conclusion from the results of this study is that achievement does not increase the tendency of entrepreneurial students at UEU, in relation to entrepreneurial students tend to be unsuccessful in achieving the highest because at the age level students will tend to be complacent even though the results have not been maximized. The third conclusion from the results of this study locus of control may increase the tendency of entrepreneurship in students at UEU Jakarta. The fourth conclusion from the results of this study is risk taking increases the tendency of entrepreneurship in students at UEU Jakarta. The courage of students in doing business or entrepreneurship certainly has taken into account the advantages and disadvantages, the courage in making decisions even though the decision is risky.

Furthermore, the conclusion of the five tolerances for ambiguity increases the tendency of entrepreneurship in students at UEU Jakarta. Uncertain circumstances will actually increase the tendency of entrepreneurship, because there are other things that are unpredictable that cause our entrepreneurship to be successful, with this uncertain situation we are required to manage it so that we can make it as new information, with the circumstances which is uncertain, we are required to be creative to plan other possible plans. The sixth conclusion from the results of this study, self confidence increases the tendency of entrepreneurship in students at UEU Jakarta. Self confidence is in the first position of the character that must be possessed by entrepreneur; self confidence is an attitude of confidence in one's own ability towards achievement and hope.

Limitations of this study can be considered for further research. This study used questionnaire as a measuring tool because of the need to save time and energy. However, the questionnaire has limitations such as bias in filling out questions. There is a possibility that the respondents did not answer the questionnaire in real terms or only filled out questionnaire answers based on the ideal conditions expected and not the actual conditions happening. This may influence the measurement used does not describe the variables 
significantly. In addition, the limited number of samples and variables may also influence the characteristics of entrepreneurship on the tendency of entrepreneurship moderated by demography of age.

This research is still very limited because it only examined the characteristics of entrepreneurship towards entrepreneurial desires moderated by age demography, thus to develop research, it is suggested that future research add other variables that can influence entrepreneurial characteristics such as financial, capital or marketing variables. Subsequent research is also expected to be carried out on other research objects such as the public, for example, youth organizations, community social associations, who desired to improve the level of welfare of each individual.

\section{REFERENCES}

1. Agung, I.G.N. 2006. Statistika: Penerapan Model Rerata-Sel Multivariat and Model Ekonometri dengan SPSS. Jakarta: Yayasan SAD Satria Bhakti.

2. Aritonang, K.T. 2013. Pengintegrasian Pendidikan Kewirausahaan Melalui Pembelajaran Terpadu Berbagai Disiplin IImu. Jurnal Pendidikan Penabur. Vol.12 (21). pp: 63-77.

3. Asamani, L., and Mensah, A.O 2013. Entrepreneurial Inclination among Ghanaian University Students: The Case of University of Cape Coast, Ghana. European Journal of Business and Management. Vol.5, No.19.

4. Aziz, A.R., Ishak, A.N., Ghani, A. P., and Othman, R. 2009. Transformational Leadership Towards World Class. University Status: Emerging Global Model Plus. Journal of Global Management Research. Fidal Institut.

5. Bezzina, F. 2010. Characteristics of the Maltese Entrepreneur. International Journal of Arts and Sciences. 3(7): $292-312$.

6. Bonnett, C., and Furnham, A. 1991. Who Wants To Be An Entrepreneur? A Study of Adolescents Interested in a Young Enterprise Scheme. Journal of Economic Psychology. 12 (3) pp. 465-478.

7. Bulut, Y., and Sayin, E. 2010. An Evaluation of Entrepreneurship Characteristics of University Students: An Empirical Investigation from the Faculty of Economic and Administrative Sciences in Adnan Menderes University. International Journal of Economic Perspectives,4(3), 559-568.

8. Dinis, A., Arminda, D.P., Ferreira, J., Raposo, M., and Ricardo, G.R. 2013. Psychological Characteristics and Entrepreneurial Intentions among Secondary Students. Journal of Small Business and Enterprise Development. 55 (8/9): 763-780.

9. Edirishinge, S.D., and Nimeshi, G.K.S. 2016. Entrepreneurial Inclination among University Students: With Special Reference to University of Kelaniya, Sri Lank. Journal of Business and Management. Volume 18, Issue 7 .Ver. II.

10. Findley, M,. and Cooper, H. 1983. Locus Control and Academic Achievement.

11. Journal of Personality and Social Psychology. 44. (2). 419-427.

12. Gurol, Y., and Atsan, N. 2006. Entrepreneurial Characteristics Amongst University Students: Some Insights for Entrepreneurship Education and Training in Turkey. Journal Education and Training. Vol. 48, Iss 1. pp. $25-38$.

13. Ibrahim, N.H., and Saili, A.R. 2017. Assessment of Entrepreneurial Inclination among the Seaweed Operator at Semporna, Sabah Using EAO Model. Economics and Entrepreneurship (JIBE). 2 (1). pp. 57-66.

14. Jackson, D.N. 1994. Jackson Personality Inventory - Revised Manual. PorHeron: MI SigmaAssessment Systems, Inc.

15. Koh, H.C. 1996. Testing Hypotheses of Entrepreneurial Characteristics: A Study of Hong Kong MBA students. Journal of Managerial Psychology. 11(3):12- 25.

16. Kotler, P., and Armstrong, G. 2012. Principles of. Marketing. New Jersey: Prentice Hall.

17. Kume, A., Kume. V., and Shahini, B. Entrepreneurial Characteristic Amongst University Students In Albani. European Scientific Journal. Vol.9, No.16.

18. Lunkapis, G.J., and Danny, H.W. (2016). Preliminary Impact Assessment of Seaweed Cultivation by the Coastal Communities in Sabah, Malaysia. Transactions on Science 
and Technology. 3(2-2), 413-420.

19. Luthje, C., and Franke, N. 2003. The Making of An Entrepreneur: Testing A Model of Entrepreneurial Intent Among Engineering Students at MIT, R and D Management. Vol. 33, No. 2, pp. 135-147.

20. Malhotra, N. 2007. Marketing Research: an Applied Orientation. Fifth Edition.

21. New Jearsey: Pearson Education, inc.

22. McClelland, D.C. 2012. Teori Motivasi. Jakarta: PT. Bumi Aksara.

23. Merredith, G.G., Robert, E.N., and Phillip, A.N. 2000. Kewirausahaan: Teori and Praktek. Penerjemah Andre Aspasayogi. Jakarta: Pustaka Binaman Pressindo.

24. Miraza, B.H. 2008. Mencermati Perilaku Enterpreneur. Medan: Penerbit USU Press.

25. Mitton, D.G. 1989. The Complete Entrepreneur", Entrepreneurship. Theory and Practice. Vol. 13,pp.9-19.

26. Mueller, S.L., and Thomas, A.S. 2000. Culture and Entrepreneurial Potential: A Nine Country Study of Locus of Control and Innovativeness. Journal of Business Venturing. Vol. 16 pp.51-75.

27. Nor, M.A., Gary, T.S., Caldwell, G.S., and Stead, S.M. 2016. Is a cooperative approach to seaweed farming effectual? An analysis of the seaweed cluster project (SPC), Malaysia. Journal of Applied Phycology.

28. Petrakis, P. 2005. Risk Perception, Risk Propensity, and Entrepreneurial Behaviour: The Greeak Case. J.Am. Acad. Bus. 7 (1).

29. Phares, E.J. 1976. Locus of Control in Personality. New Jersey: General Learning Press.

30. Schumpeter, J. 2014. Change and the Entrepreneur" in Essays of J.A.

31. Sexton, D.L., and Bowman, N. (1985). The Entrepreneur: A Capable Executive and More. Journal of Business Venturing. Vol. 1(1):129-140.

32. Sugiyono. 2012. Metode Penelitian Kuantitatif, Kualitatif, and R\&D. Bandung: Alfabeta.

33. Tung, L.C. 2011. The Impact of Entrepreneurship Education on Entrepreneurial Intention of Engineering Students. City University of Hongkong: Run Run Show Library.

34. Yusof, M., Sandhu, M.S., and Jain, K.K. 2007. Relationship Between Psychological Characteristics and Entrepreneurial Inclination: A Study od Students at University Tun Abdul Razak. Journal of Asia Entrepreneurship and Sustainability. Volume III, Issue 2.

35. Zaman, M. 2013. Entrepreneurial Characteristics among University Students: Implications for Entrepreneurship Education and Training in Pakistan. African Journal of Bussiness Management. Vol. 7(39), pp. 4053-405.

36. Zimmerer, T.W., Scarborough, N.M., and Wilson, D. 2009. Kewirausahaan and Manajemen Usaha Kecil. Edisi 5. Buku 2. Jakarta: Penerbit Salemba Empat. 